\author{
Lenore A. Grenoble ${ }^{1}$, Jessica Kantarovich ${ }^{1}$, Irena Khokholova ${ }^{2}$ and \\ Liudmila Zamorshchikova² \\ ${ }^{1}$ The University of Chicago, ${ }^{2}$ M. K. Ammosov North-Eastern Federal University \\ grenoble@uchicago.edu
}

\title{
Evidence of syntactic convergence among Russian-Sakha bilinguals
}

\begin{abstract}
This paper illustrates the implementation of two basic experiments to test word order changes in Russian and Sakha, languages in long-standing contact. We hypothesize that changes in word order may correlate with deeper structural changes and language shift. The experiments show that some speakers are shifting from Sakha to Russian: 4 from a sample of 30 speakers could not produce texts in Sakha, and one third of the sample produced sentences with some errors. At the same time, there were a significant number of mistakes in the Russian production experiments, indicating interference from Sakha and/or imperfect learning. A sociolinguistic questionnaire showed a high level of accuracy between speakers' self-assessment of their proficiency in each of the target languages as measured by the experiments shown here. Moreover, the simple experiments themselves revealed a number of other production errors and proved to be a reasonable indicator of less than fluent proficiency and of at least the initial stages of language shift.
\end{abstract}

\section{Diminishing diversity}

In this paper we explore the issue of what we call diminishing diversity from two different angles. One is the question of language endangerment and language loss, which reduces the absolute number of languages being spoken. Another is contact-induced change and linguistic convergence, which results in a reduction in the number of distinct linguistic phenomena in a particular linguistic area. Structural convergence (with reduced typological diversity) is not a guaranteed result of language contact; that is, contact-induced change can also promote the diffusion of certain linguistic features without the replacement of existing structures in the languages undergoing change. In some cases, contact has even resulted in the creation of new languages and new language types: for example, Vakhtin (1998) argues that the creation of a mixed variety, Copper Island Aleut, illustrates this scenario. In this paper, we consider the case of contact between Russian and Sakha, which 
has taken place in a socially unbalanced setting, where Russian is becoming increasingly dominant. We conclude that both languages display some contact-induced change, with clear structural convergence on Russian word order patterns in Sakha. We also conclude that Sakha shows the beginning stages of language shift, which could ultimately contribute to a reduction in the diversity of languages spoken in the Sakha Republic.

\subsection{Language contact in the Russian-speaking world}

Across Eurasia, speakers of Russian have been in contact with speakers of a number of other languages for centuries. These languages occupy a wide geographic area and are typologically and genealogically distinct from one another. Additionally, even related languages at times vary considerably in terms of their local language ecologies: we find differences in the basic demographics of the speaker population (such as the number of speakers and their ages), the number of languages spoken, and the degree of multilingualism and linguistic proficiency in the different languages. Due to migration and evolving political and economic pressures, these ecologies are regularly in flux — they are dynamic, not static, systems.

At present, there is massive and rapid shift to Russian across Siberia and the Russian Far North; thus, we find language loss in addition to contact-induced change. In this paper we evaluate the status of Russian and Sakha contact. Sakha is typologically distinct from and unrelated to Russian, which has typical IndoEuropean fusional morphology. Sakha (Turkic, ISO 639-3 sah) is head final and has characteristic agglutinating morphology. Of direct relevance here is that it has consistent verb-final word order and is characterized by differential object marking: the accusative case is used to mark definite or specific objects, while there is no unique marking for nonspecific indefinite objects, and they are morphologically indistinguishable from the nominative, which is phonologically unmarked (Baker and Vinokurova 2010). In Russian, neutral word order is SVO but is generally conditioned by information structure.

Sakha is robustly spoken, although not all ethnic Sakha speak it; $93 \%$ of ethnic Sakha speak their language, from a population of 466,492. Bilingualism is widespread in the Republic of Sakha, which has an estimated population of 964,330 as of 2018 (Federal State Statistics, 2018). 89\% of ethnic Sakha speak Russian, although this number is lower in rural areas (Ferguson 2016), and 93\% of the total population of the Republic speaks Russian (Vinogradova 2016). Thus the Sakha Republic as a whole is overwhelmingly Russian-speaking, and the Sakha language shows early signs of language shift. It seems accurate to consider it vulnerable, but not yet threatened or endangered. This is reflected in speakers' own perceptions of the retention of their language: speakers tend to be more preoccupied with continued maintenance and transmission to new generations than active revitalization. 


\subsection{The Sociopolitical Context of Russian and Sakha}

Russian is the national language of the Russian Federation. Its use is guaranteed by the Russian constitution. In the Republic of Sakha (Yakutia), the Sakha language enjoys special official status as guaranteed by the Republic's language law, adopted in 1992 and updated in 2017 (Language Law of the Republic of Sakha (Yakutia)). The Sakha language is the official state (gosudarstvennii) language of the Republic (Article 3). Russian is also a state language, and the language of interethnic communication (or iazyk mezhnatsional'nogo obshcheniia; Article 5). The law further recognizes the other local Indigenous languages as official languages in those regions where the people live, with equal status as the state languages, at least in theory. Article 2 of the Law guarantees people of any group the right to use their language. Still, Russian has replaced Sakha as the lingua franca of the Republic, not only by law but also by practice, in the majority of the region.

The Sakha Republic is multilingual, and home to speakers of a number of different languages, both autochthonous and immigrant. In addition to Sakha, there are 5 languages spoken in the Republic that have official status as minority Indigenous languages in the Russian Federation. They are: Even and Evenki (Tungusic), Dolgan (Turkic), Chukchi (Chukotko-Kamchatkan), and Yukaghir (possibly Uralic). Yukaghir is officially classified as a single language, but on the basis of mutual unintelligibility linguists recognize two distinct languages: Tundra and Forest Yukaghir. Ethnolinguistic groups of less than 50,000 in Russia are officially classified as small-numbered (maločislennye), a concept that is often used in Russia to correspond to peoples who are called Indigenous in the West. These groups are characterized by rapid and advanced language shift, and extensive language loss is particularly prevalent among Northern Indigenous groups. Note that following this system, Sakha people are not indigenous in the legal sense, as the population is well over the 50,000 threshold.

\section{Word order in contact-induced change}

Word order is a fruitful area to consider in a contact setting for a number of reasons:

(i) Word order is well-known to be susceptible to contact-induced change (Heine 2008). There is reason to suspect that there might be word order changes in the Russian-Sakha setting, as they are widely attested in numerous other contact situations. Word order is also known to correlate with a number of other typological parameters (Dryer 2007; Song 2001: 49-137), and changes in word order might indicate other structural changes. Thus, for example, if Sakha is shifting to VO order, we might also find indications of other syntactic changes, such as the appearance of prefixation, prepositions, and finite subordinate clauses. These predictions are based on the hypothesis that word order is harmonic, or consistent, within a language, and these correlations are functionally and structurally motivated 
(Dryer 1992; Hawkins 2009: 54-78). Alternatively, perhaps only the word order is changing. Whether word order changes entail other syntactic changes remains an open empirical question; Dunn et al. (2011) argue that it does not.

(ii) Word order does not appear to index social identity. There is no indication that word order varies with social group, and the vast literature on word order typology and change does not link word order variation to social indexing (see e.g. Song 2001; Trudgill 2011).

(iii) Word order distinctions appear to be more formal and do not have semantic value (Hickey 2010, forthcoming). Both points (ii) and (iii) are important for the present study, as we hypothesize that word order changes could be among the first to occur in contact situations precisely because certain word orders do not have semantic or social value. In other words, they can occur without changes in meaning, broadly construed, and their adoption (or retention) is likely to be purely structurally motivated.

(iv) Word order changes under contact between Slavic and Turkic are attested elsewhere, e.g., in the Balkans with the case of West Rumelian Turkic. West Rumelian Turkic shows a number of differences from Standard Turkic, as illustrated in example (1)1 with West Rumelian Turkish (WRT), Macedonian (M) and Standard Turkish (ST):

(1) West Rumelian Turkish (adapted from Ibrahimi 1982: 35; cited in Friedman 2017)

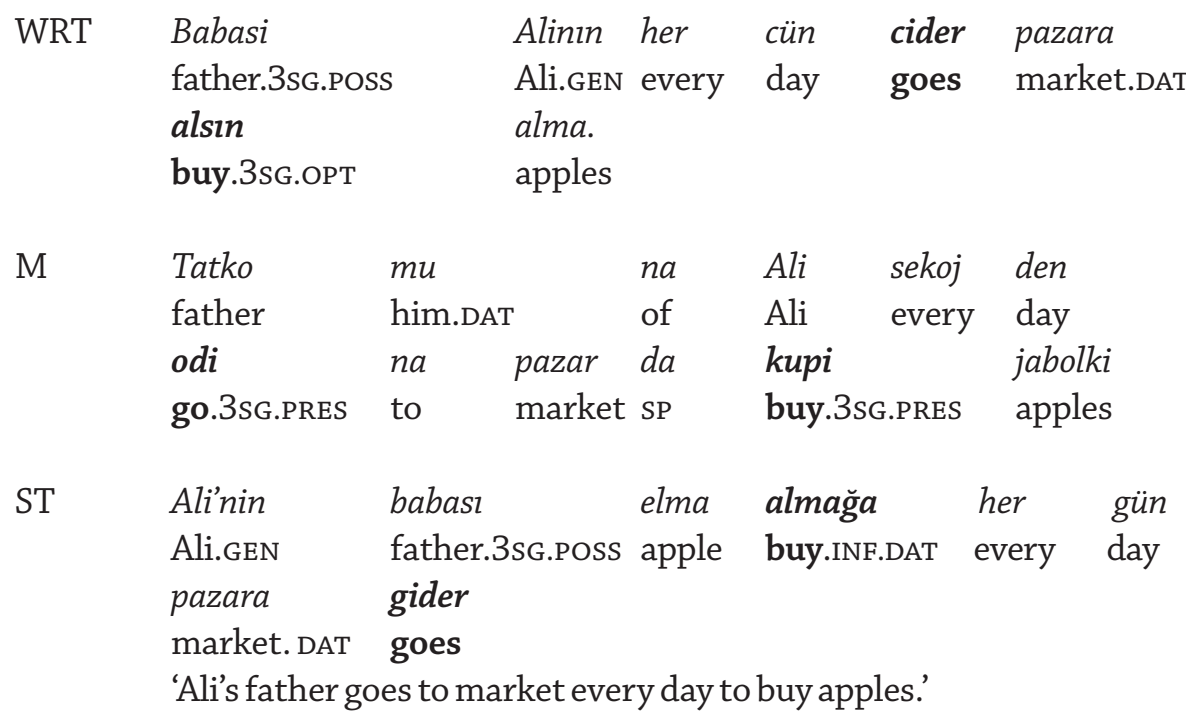

1 We follow Leipzig Glossing Rules throughout, with the addition of C.RECIP for the cooperative-reciprocal morpheme in Sakha, and EPEN.v for the epenthetic vowel. 
The three sentences in (1) illustrate a set of changes that are typical of the Balkans. In Standard Turkish the finite verb is predictably at the end of the sentence; the nonfinite clause precedes it. In contrast, in Macedonian the finite verb of the main clause (odi 'goes') precedes the embedded clause, which itself uses a finite verb (kupi 'buys') instead of the morphological infinitive. We find morphosyntactic change in the dependent clause of West Rumelian Turkish, which shows replication of the Macedonian pattern of using a finite verb in embedded clauses. Instead of the expected infinitive form, WRT uses an optative finite verb (alsin 'would buy') in the embedded clause, much like Macedonian. This pattern is widespread in Balkan Turkish under Macedonian and Albanian influence (Friedman 2006: 38). In WRT, we also find that neither verb form is clause- or sentence-final.

In both Standard and West Rumelian Turkish, the possessed NP 'Ali's father' shows double marking but the word order differs, with the head following the dependent in the Standard variety and preceding it in WRT, as in Macedonian. Note that the morphology itself is unchanged.

Thus, the sentences in (1) illustrate that word order changes can occur with and without morphosyntactic restructuring, and that such changes are attested in languages with a fairly rigid word order.

We can now turn to Russian-Sakha contact, which is another instance of contact between Turkic and Slavic, but within a different language ecology. Although there are a number of different languages spoken in the Republic of Sakha, Russian is clearly dominant in many domains, including education and the media. Speakers of Sakha are also in contact with speakers of Dolgan, closely related to Sakha, and Even and Evenki, two Tungusic languages that are typologically very similar to Sakha (OV order is also preferred). Thus we consider two contrary possibilities that are both compatible with an areal explanation: contact with Dolgan and Tungusic might reinforce OV order, or contact with Russian might promote a change to VO order.

Word order changes can be challenging to identify, particular in initial stages, as information structure often plays a role even in the most rigid languages. ADD REF (In languages that do not have a very rigid order, imaginative speakers will frequently accept all or most typologically possible orders, if there is a plausible context in which they might occur.) Here, we have attempted to control for pragmatically-conditioned variation in word order by setting up a context-neutral experiment.

\section{Word order changes in Sakha and Russian}

In order to test word order in a systematic way, we devised two simple experiments, described in detail in Sections 3.2 and 3.3. The experiments were conducted with 30 students from Northeastern Federal University (NEFU) in Yakutsk, Sakha, in October 2017. The students came from different parts of the Sakha Republic 
and were all in their first or second year of university education. The students were born in the years 1993-1998 (ages 19-24 at the time of the experiments). All 30 students self-identified as ethnic Sakha and they also completed a sociolinguistic survey to ascertain their language attitudes and to give their own assessment of their language proficiency. It should be noted that instruction at NEFU is in Russian, and students must be highly proficient in Russian to be admitted. However, some students noted that Russian was not their first language and that they felt more comfortable using Sakha (Section 3.1). Students were asked to perform both experiments in Sakha and then to perform experiment \#1 again in Russian. Those students who did not speak Sakha at all were asked to do both experiments in Russian only.

These experiments were used to test the following predictions:

1. We anticipate that speakers who are Russian-dominant are more likely to use SVO word order in Sakha than their counterparts who are Sakha-dominant.

2. Conversely, we might expect to see SOV order in Russian more often among Sakha-dominant speakers.

3. We thus predict that balanced bilinguals would maintain the word order of each language. Alternatively, we might expect Sakha morphology to be retained but show a tendency toward Russian word order, i.e., a movement toward VO order. (Such changes have been anecdotally reported for other languages in contact with Russian; we found no evidence of Sakha-Russian convergence of this kind in these experiments.)

In this initial stage of our research, we did not run independent assessments of language proficiency, but relied on self-reporting. There is a strong correlation between self-assessment and performance on these simple experiments, providing evidence that supports speakers' self-awareness of their abilities. Indeed, in the sociolinguistic interviews conducted with the students, they spoke in great detail about their proficiency and about domains in which one language or another was preferred.

\subsection{Attitudes and self-assessment}

All participants were asked to complete a basic sociolinguistic questionnaire and were asked questions by one of the examiners about their language proficiency and attitudes. Although two students claimed lack of Sakha proficiency, they were able to complete Experiment \#2 when they realized that the lexical items were supplied with the experiment.

Of the 30 total participants, all spoke Russian, with only 2 reporting any difficulty in speaking the language. In contrast, 2 participants claimed not to speak Sakha at all, while another 7 reported limited proficiency. This is summarized in Table 1: 


\begin{tabular}{|l|r|}
\hline Total number of speakers & 30 \\
\hline speak Russian & 30 \\
\hline some difficulty with Russian & 1 \\
\hline speak only Russian & 2 \\
\hline only comfortable speaking Russian & 3 \\
\hline speak Sakha & 28 \\
\hline some difficulty with Sakha & 2 \\
\hline only speak Sakha (no literacy) & 5 \\
\hline & \\
\hline fully functional speakers of Sakha & 21 \\
\hline
\end{tabular}

Table 1. Speaker Proficiency Self-Assessment

\subsection{Experiment 1}

The first experiment used tightly controlled lexical items and stimuli, to enable direct comparison of data across speakers. Subjects were presented with a single picture and 3-4 lexical items, in citation form, and asked to form a sentence using those words to describe the picture. Each picture featured a self-contained event to establish a situation that was as context-free as possible, since Russian word order is largely determined by information structure. The verb was presented first in each case, with the rationale that none of the sentences were expected to begin with the verb in either language. (Verb initial position is possible in Russian, but is highly marked and would require a supporting context.)

A total of 14 pictures were used in this experiment; 9 used ditransitive verbs so as to test both case usage and word order without adding temporal or spatial adverbials, which are often found in the beginning of sentences in both Russian and Sakha. A sample picture from the experiment is given in Figure 1:

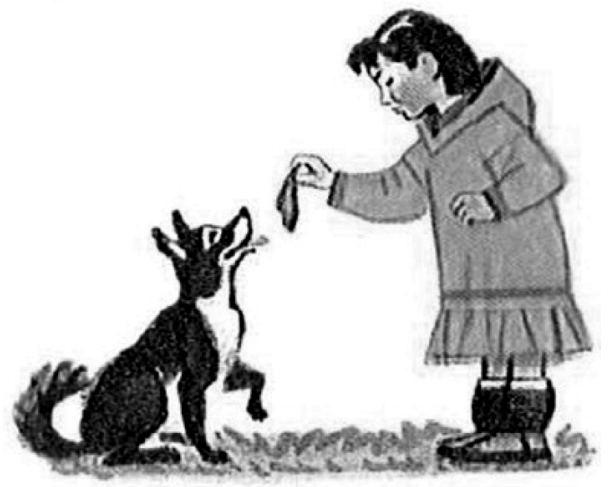

Figure 1. Picture 3 
Stimuli words were presented on an index card in Cyrillic, one language per card, written in column form. The stimuli for Picture 3 are given in (2), in the order provided in the experiment, with the Cyrillic transliterated and English glosses:

\begin{tabular}{|c|c|c|}
\hline ) Russian & Sakha & English \\
\hline kormit' & ahat & 'to.feed \\
\hline sobaka & $\ddot{i t}$ & 'dog' \\
\hline devočka & kiïs & 'girl' \\
\hline mjaso & et & 'meat' \\
\hline
\end{tabular}

Note that there is considerable dialect variation in Sakha with regard to the lexicon, and speakers sometimes suggested different words from the ones provided in the experiment. In these cases we simply accepted the substitution and replaced our stimuli with their preferred terms. This did not affect word order.

For picture \#3, we expected fluent speakers to produce the sentences in (3), with the finite verb in boldface:

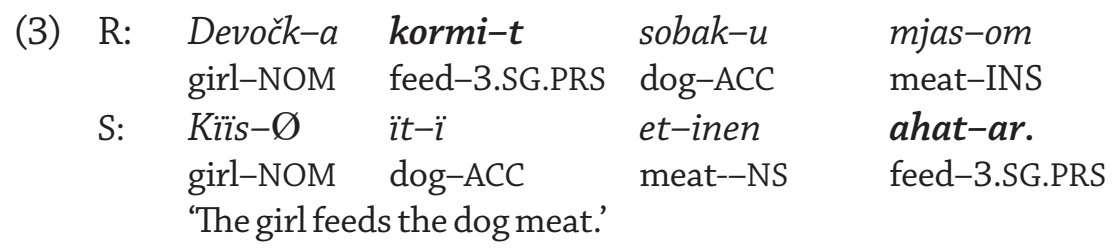

In the Russian version, the verb is second position, immediately following the subject, while in Sakha, the verb is at the end of the sentence. Each sentence provides the neutral, unmarked, or preferred word for each respective language.

To return to our initial hypotheses, we predicted that under Russian influence Sakha would show SVO order, and, in the reverse case, Russian would exhibit SOV order. No speakers produced verb-final order for any of the sentences in Russian. There were some non-standard uses of Russian case, which we describe in Section 4.

The Sakha version of this experiment produced more interesting results. There were a number of deviations from verb-final word order, as well as a number of other mistakes. One speaker produced SVO order in all sentences and another one did so in most sentences. Example (4a) provides an illustration of a sentence with word order changes versus standard word order in Sakha (4b); note that the morphology is the same in both instances:
a. Produced: $A$ : d'axtar $\varnothing$
$\check{c} e j$
onor-or
kïis-ka
ah mother-NOM tea
make-3.SG.PRS
girl-DAT
b. Standard: $A$ : d'axtar- $\varnothing$
$\check{c} e j$
kiïs-ka
onor-or
ah mother-NOM tea
girl-DAT
make-3.SG.PRS
'Ah, the mother makes tea for the girl.' 
The word order seen in (4a) is viewed by 4 native speakers who reviewed the data as a mistake, but it does not interfere with comprehension. All speakers who exhibited word order changes produced similar patterns: the order was SVO, but the verb is not given in second position for most speakers, as would be expected in neutral Russian word order. The number of such deviations varied, with 2 speakers moving the verb in only 1 sentence and 1 speaker using SVO order in all 14 sentences. These results are summarized in Table 2:2

\begin{tabular}{|c|c|c|}
\hline speaker data & number of VO sentences & sentence(s) \\
\hline \#32, F, b. 1998; from Yakutsk & 14 & $1-14$ \\
\hline \#07, F, b. 1997; from Yakutsk & $8-15$ & $\begin{array}{c}1-3 ; 6 ; 8,9,11 ; \text { or } \\
1-9 ; 11-14\}\end{array}$ \\
\hline $\begin{array}{c}\text { \#37, F, b. 1997; birthplace not } \\
\text { given }\end{array}$ & 3 & $1,2,3$ \\
\hline $\begin{array}{c}\text { \#14, F, no birthdate; birthplace } \\
\text { not given }\end{array}$ & 1 & 2 \\
\hline $\begin{array}{c}\text { \#34, F, no birthdate; from Ole- } \\
\text { kmin region }\end{array}$ & 12 \\
\hline
\end{tabular}

Table 2. Speakers with VO word order

The two speakers with the most word order errors, \#32 and \#07, have low proficiency based on the results of this experiment, using little to no morphology. Speaker \#32 uses Russian word order (V2) but has no control of morphology; she simply uses the citation form of the words provided in the prompts. It is difficult to assess the word order in some Speaker \#7's responses, as most of the sentences have so many mistakes that they could reasonably be excluded from analysis. There are some clear cases of the verb in final position, as in (5):

$\begin{array}{llll}\text { (5) P10 } & \text { Kï̈s- } \varnothing & \text { kuukla- } \varnothing & \text { körodör-ör. } \\ & \text { girl-NOM } & \text { doll-NOM } & \text { show-3.SG.PRS } \\ & \text { 'The girl shows the doll.' } & \end{array}$

The results here strongly indicate some Russian influence, as VO order is not expected in any of these sentences. The experiment was designed to prompt the production of sentences that would not be influenced by information structure, and indeed, in standard Sakha we anticipate rigid verb-final order anyway.

\subsection{Experiment 2}

In the second experiment, participants were shown a sequence of four pictures and asked to create a narrative that described the events in the pictures. The pic-

2 Counting mistakes is hampered by the lack of morphology; a number of the sentences are best considered ill-formed. 
tures were printed on a single sheet of paper so that the participants could view them all at once, so as to enable them to conceptualize a connected narrative. The pictures are provided in Figure 2:
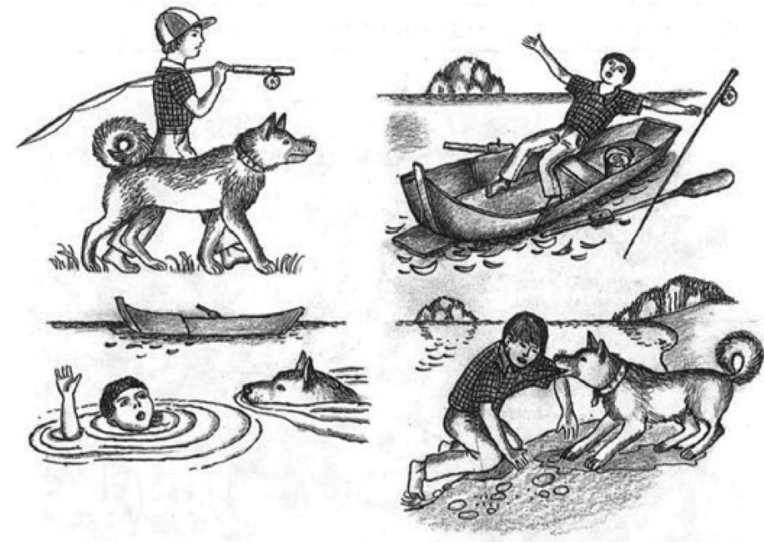

Figure 2. Four-picture sequence used for Experiment 2

The selection of a brief text was deliberate. Previous work with longer story books used to elicit narratives in the Russian North did not produce the desired result: speakers found the story too long and boring. Many did not create a coherent narrative as they told the story, but provided a separate description of each page, with minimal linkage between events. By providing 4 connected pictures, speakers were able to construct a brief, coherent text.

A total of 26 subjects completed the task in Sakha. The two speakers who had self-identified as monolingual Russian speakers did not attempt the task, nor did the two speakers who had considerable problems with Experiment 1 (\#7 and \#32, Table 3); since we did not supply the lexicon in this experiment, it was considerably more challenging for those speakers. Thus we received a total of 26 texts; these ranged in length from 1-8 sentences. 22 of the texts were consistently verb-final. In 4 of the texts we find VO word order: in 3 out of 4 sentences for one speaker, in 2 out of 5 sentences for another; and two other speakers each had 1 VO sentence. (One of these speakers, \#37, also displayed word order issues in Experiment 1.) These results are summarized in Table 3 :

\begin{tabular}{|c|c|c|c|}
\hline speaker & total sentences & OV & VO \\
\hline$\# 31$ & 4 & 1 & 3 \\
\hline$\# 18$ & 5 & 3 & 2 \\
\hline$\# 10$ & 8 & 7 & 1 \\
\hline$\# 37$ & 6 & 5 & 1 \\
\hline
\end{tabular}

Table 3. Summary of results, Experiment 2 
If word order is the only parameter taken into account, these changes might appear to be negligible, as only 4 out of 26 used VO word order ${ }^{3}$. But they are significant, as any order except verb-final should be strongly dispreferred. Moreover, from the larger initial sample of 30 speakers, we see that only 22 created brief narratives containing only verb-final word order (with 4 speakers using some SVO, and 4 speakers being unable to produce an unguided narrative at all). Three of the speakers that produced VO word order in Experiment 2 (\#31, \#18, and \#10) did not do so in Experiment 1, where they consistently produced OV orders. This can likely be explained by the nature of the tasks: in Experiment 1, speakers had more time for utterance planning and were provided with the exact words to use in constructing a single sentence, and may have been more conscious of providing the most grammatical-sounding word order. In contrast, in Experiment 2, speakers produced the full narrative (composed of multiple sentences in a single stream of speech), which afforded them less time to plan individual sentences, and may more-closely mirror everyday conversational speech.

Somewhat counterintuitively, some of the speakers who produced VO order in Experiment 1 and were able to participate in Experiment 2 (\#14 and \#34) produced the expected word order in their narratives. Each of these speakers only produced one VO sentence in the first experiment, suggesting that this is at most a moderate tendency in their speech; an 8-sentence narrative may have simply been too short to elicit any instances of nonstandard word order.

\section{Experiment 1 in Russian}

The Sakha speakers were asked to repeat experiment 1 in Russian. They were provided with the same pictures and Russian equivalents of the lexical items. No one used verb-final order in Russian. At this stage, there are no indications that word order in Russian is changing under Sakha influence, based on this simple experiment with a small sample.

The resulting texts were transcribed and evaluated by a native speaker of Russian from Moscow who does not speak Sakha (and has never been to the Republic), in addition to being evaluated by the authors. Sentences with errors were evaluated by a second native Muscovite. 25 out of 30 speakers made one or more mistakes in the Russian production experiment. Those 4 speakers who do not have any functional use of Sakha (the 2 who declared themselves to be monolingual speakers, and speakers \#7 and \#32) did not make any mistakes in the Russian texts. The mistakes can be classified into the following types:

3 A reviewer notes that this result appears to suggest that Russian influence was more apparent in Experiment 1 than in Experiment 2, since a greater number of participants displayed nonstandard word order in Experiment 1. This is a spurious conclusion, due to the fact that 2 of the speakers who struggled with the first experiment lacked the proficiency to participate in the second experiment entirely; thus, on the whole, the second experiment actually suggests a greater extent of Russian influence on Sakha language use. The differences in performance between the two experiments is discussed in further detail below. 


\subsection{Mistakes in case}

Particularly frequent was the use of the nominative case for an expected accusative, as in the following examples:

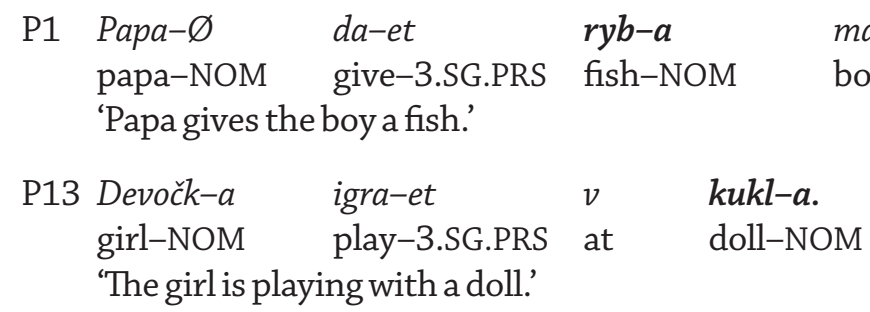

Instead of an expected accusative in (6) and (7), we find the nominative (ryba 'fish' and kukla 'doll'). The accusative is absolutely required for the direct object in these constructions in Russian, but the case marking is unambiguously nominative singular. (Neither ryba nor kukla display any syncretism in their case marking; their expected accusative forms are rybu and kuklu.) The mistakes in these two examples appear to be the result of interference from Sakha, which uses an unmarked nominal (that coincides with the nominative case) for nonspecific objects, instead of a morphological accusative. Stoynova (2018) reports similar findings for Russian speech in contact with Nanai (Tungusic), where speakers also appeared to impose the Nanai pattern of differential object marking on their Russian.

The most frequent mistake in case (11 instances) is found in (8):

(8) $\mathrm{P} 14$

$\begin{array}{llll}\text { Mal'čik- } \varnothing & \text { stro-it } & \text { dom- } \varnothing & \text { kubik-ami. } \\ \text { boy-NOM } & \text { build-3.SG.PRS } & \text { house-ACC } & \text { block-INST.PL } \\ \text { 'The boy is building a house with blocks.' } & \end{array}$

Just over one-third of all speakers used an instrumental instead of the expected preposition iz + genitive case (iz kubikov 'from blocks'), required here as the blocks are the substance from which the house is built, not the tool used to build them (where the instrumental would be more standard). Overuse of the instrumental case is also found in Sentence 5, where snežk-ami 'with snowballs' is seen instead of the expected accusative (snežki):

Mal'cik- $i \quad$ brosaj-ut
boy-NOM.PL throw-3.PL.PRS
drugvdrug-a.
other at other-ACC

'The boys are throwing snowballs at one another'

This is almost certainly the result of interference from Sakha, where the construction with the verb bIrax- 'throw' requires the reflexive and an instrumental 
complement. In the Sakha version of this phrase produced by speakers in Experiment 1 , we do indeed find use of the instrumental case as in (8a):

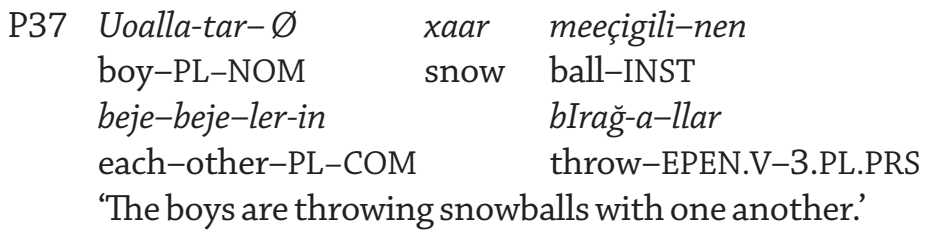

According to the norms of the Sakha standard language, the expected form of the verb in (8a) is the cooperative-reciprocal (birax-s-a-llar throw-C.RECIPEPEN.V-3.PL.PRS). In (8a), the speaker uses just the comitative form of the nominal bejebejelerin 'with one another' to convey this meaning, but the grammatical norms require cooperative-reciprocal marking on the verb as well. We hypothesize that this could be interference from the two possible constructions in Russian, with a transitive verb and accusative direct object (brosat'snežki) or with a derived intransitive and an instrumental complement (brosat'sja snežkami). Thus it is likely that overuse of the instrumental here occurs as interference.

\subsection{Lexical issues and verbs}

A number of mistakes were found with particular verbs and certain lexical items; a number of these are generally known to cause difficulties for L2 speakers of Russian. For example, the verb učit' to teach to VERB' takes an infinitive complement in Russian, but a number of speakers added kak 'how'

$\begin{array}{lllll}\text { (9) P5 } & \text { Babušk- } a & u c ̌-i t & k a k & \text { gotovi-t' } \\ & \text { grandmother-NOM } & \text { teach-3.SG.PRS } & \text { how } & \text { cook-INF } \\ & \text { 'The grandmother teaches (how) to cook.' } & & \end{array}$

This verb is known to be problematic for $\mathrm{L} 2$ speakers of Russian; Rakhilina et al. (2016: 15-16) note problems that Heritage Russian speakers who are L1 speakers of English have with this verb, noting a tendency to calque from English ("how to cook'). Its use here is also likely to be due to interference from Sakha, but the explanation is somewhat different. In the standard language we would expect to see (9a) as a neutral statement of the facts providing general information:

$\begin{array}{llll}\begin{array}{l}\text { Ebee- } \varnothing \\ \text { grandmother-NOM }\end{array} & \text { as- } \varnothing & \text { astiirg- } a & \text { uöret-er } \\ \text { food-NOM } & \text { cook-CVB } & \text { teach-3.SG.PRS } \\ \text { 'The grandmother teaches to cook.' } & & \end{array}$

But emphasis on teaching the girl HOW to cook, as opposed to teaching her simply to cook, would result in (9b), with the use of xajdax 'how': 


\section{(9b) P5 Ebee- $\varnothing$}

xajdax as- $\varnothing$ astiirga uöret-er
grandmother-NOM how food-NOM cook-CVB teach-3.SG.PRS
'The grandmother teacheshow to cook.'

In the Russian version of this sentence, use of kak is ungrammatical, but in Sakha provides specific emphasis on the manner (how).

Both sets of mistakes are seen in sentence 12, where some speakers had problems with the verb, some with the noun sanki 'sled' (pluralia tantum in Russian) and some had problems with both. Example (10) provides the target sentence:

$\begin{array}{clrll}\text { P12 Mal'čik- } \varnothing \quad i \quad \text { devočk-a } & \text { kataj-utsja na sank-ax. } \\ \text { boy-NOM and girl-NOM } & \text { go.sled-3.PL.PRS } & \text { on } & \text { sled-PREP.PL } \\ \text { 'The boy and girl are sledding.' } & & \end{array}$

In the elicited sentences there were a range of mistakes involving subject-verb agreement and the noun sanki, which was in some cases given in the singular instead of the required plural. Picture 12, the stimulus for (10), had the highest number of errors, with 12 speakers making mistakes; picture 14 (in example (7)) had the second highest, 11 speakers; and the third was sentence 5 (example (9)) with 9 errors. The remaining picture-stimuli sets showed only $1-4$ errors for the entire sample. In general the mistakes were not random, but appeared to be associated with particular lexical items: the verb učit' 'to teach' in (ex. 9/P5); sanki 'sled' (ex. 10/P12) or lexical constructions as stroit' ot + genitive 'build from something' (ex. 7/P14), where the governance pattern needs to be learned.

\subsection{Summary}

The majority of speakers ( 24 out of 30 ) completed the Russian task with at least one mistake; for 4 speakers, the only mistake was the use of the instrumental case (kubikami 'with blocks') in Sentence 14, seen in (7). The mistakes show some interference from Sakha, as in examples (7) and (8), alongside imperfect learning of Russian, as in examples (9) and (10). While the errors in (9) and (10) could conceivably be explained through limited exposure to the behavior of those particular words, the errors in sentences (7) and (8) are evidence of more generalized issues with Russian case marking.

\section{Discussion}

The results of this preliminary study indicate some shift from Sakha to Russian. This is manifested both in terms of varying levels of language loss and interference from Russian. To return to the original total count of 30 speakers, only 26 could produce well-formed sentences when provided with the necessary lexical items, and similarly only those 26 could produce a text describing the pictures in experiment 2 without the lexicon provided. Although all 26 produced verb-final 
syntax, here too it was not consistent, as 3 speakers produced 1-3 sentences each with a non-final verb in experiment 1 . And the results of experiment 2 show definite change, as only 22 speakers produced only verb-final syntax when asked to freely create a short text.

All speakers have high-level knowledge of Russian; we know this independently from the fact that they all passed the Unified State Exam (èdinyj gosudarstvennyj èkzamen), required for graduation from high school and for entrance to the university. Nonetheless, more than half of the speakers made some mistake in the Russian production task, experiment 1 , where the lexical items were provided. The next task in our study is to replicate the experiment with monolingual Russian speakers living outside of the Sakha Republic, in an urban center such as Moscow or St. Petersburg in the western part of Russia, where there is limited to no contact with speakers of a Turkic language.

Contact effects occur in both languages in this sample, but word order changes are seen only in Sakha. There is no a priori reason to assume that this would be the case, and only 1 speaker self-identified as Sakha dominant (Table 1). We predicted that we might find word order changes in Russian, but found no evidence of this effect. No speakers produced verb-final word order in Experiment 1 or 2.

\section{Acknowledgements}

Research on this project was funded by the Humanities Council of the University of Chicago, and the US National Science Foundation, BCS\#1761551 Investigating language contact and shift through experimentally-oriented documentation, and further supported by Northeastern Federal University in the name of M.K. Ammosov, and MultiLing, the Center for the Study of Multilingualism across the Lifespan at the University of Oslo. We would like to thank Ming Xiang for all her help in setting up the experiments, and Veronika Migalkina and Gregoriy Gorbun for their work with data transcription and analysis.

\section{References}

Baker, Mark and Nadezhda Vinokurova (2010). Two modalities of case assignment in Sakha. Natural Language and Linguistic Theory 28(3): 593-642, https://doi.org/10.1007/s11049-010-9105-1

Dryer, Matthew S. (2007). Word order. Timothy Shopen, ed. Language Typology and Syntactic Description, 2nd ed., Vol. 1: Clause Structure. Cambridge: Cambridge University Press, 61-131

Dryer, Matthew S. (1992). The Greenbergian word order correlations. Language 68: 81-138

Dunn, Michael, Simon J. Greenhill, Stephen C. Levinson and Russell D. Gray (2011). Evolved structure of language shows lineage-specific trends in word-order universals. $\mathrm{Na}$ ture 473: 79-82, https://doi.org/10.1038/nature09923 
Federal State Statistics (2018). Chislennost' postojannogo naselenija Rossijskoj Federacii po municipal'nym obrazovanijam na 1 janvarja 2018 goda. [Population count of the permanent residents of the Russian Federation by municipality as of 1 January 2018] http:// www.gks.ru Accessed 23 April 2019

Ferguson, Jenanne (2016). Language has a spirit: Sakha (Yakut) language ideologies and aesthetics of sustenance. Arctic Anthropology 53(1): 95-111, https://doi.org/10.3368/ aa.53.1.95

Friedman, Victor A. (2006). West Rumelian Turkish in Macedonia and adjacent areas. Boeschoten Hendrik and Johanson Lars, eds. Turkic Languages in Contact. Weisbaden: Harrassowitz, 27-45

Friedman, Victor A. (2017). Languages of the Balkans. Oxford Research Encyclopedia in Linguistics. Oxford: Oxford University Press, https://doi.org/10.1093/acrefore/9780199384655.013.348

Heine, Bernd (2008). Contact-induced word order change without word order change. Siemund, Peter and Noemi Kintana, Noemi, eds. Language Contact and Contact Languages. Amsterdam: John Benjamins, 33-60, https://doi.org/10.1075/hsm.7.04hei

Hickey, Raymond (2010). Contact and language shift. Raymond Hickey, The Handbook of Language Contact. London: Wiley-Blackwell, 151-169

Hickey, Raymond (forthcoming). Contact and language shift. Raymond Hickey, The Handbook of Language Contact. 2nd edition. London: Wiley-Blackwell

Ibrahimi, Sami (1982). Ndikimi i gjuhës shqipe në rrafshin fonologjik të turqishtes së folur në Maqedoni dhe Kosovë [The impact of Albanian phonology on Turkish spoken in Macedonia and Kosovo]. Studime fililogjike 36(2): 51-61

Language Law of the Republic of Sakha (Yakutia). [Zakon Respubliki Sakha (Iakutiia) ot 16 oktiabria 1992 goda N 1170-XII. ] O iazykakh v Respublike Sakha (Iakutiia) http://docs.cntd.ru/document/804911252 Accessed 07 September 2018

Rakhilina, Ekaterina, Anastasia Vyrenkova and Maria Polinsky (2016). Linguistic creativity in heritage speakers. Glossa 1(1), 43: 1-29, https://doi.org/10.5334/gjgl.90

Song, Jae Jung (2001). Linguistic Typology. Morphology and Syntax. London: Longman

Stoynova, Natalia (2018). Differential object marking in contact-influenced Russian speech: Evidence from the corpus of contact-influenced Russian speech of Russian Far East and Northern Siberia. Computational Linguistics and Intellectual Technologies: Proceedings of the International Conference "Dialogue 2018." http://www.dialog-21.ru/media/4336/stoynovanm.pdf

Trudgill, Peter (2011). Sociolinguistic Typology. Social Determinants of Linguistic Complexity. Oxford: Oxford University Press

Vakhtin, Nikolai (1998). Copper Island Aleut: A case of language "resurrection." Grenoble, Lenore and Whaley, Lindsay, eds. Endangered Languages: Language Loss and Community Response. Cambridge: Cambridge University Press, 317-327, https://doi.org/10.1017/CBO9781139166959.014

Vinogradova, Polina (2016). Prikazali pomnit'. V Jakutii spasajut ischezajushchie jazyki narodov severa. [They ordered us to remember. In Yakutia the endangered languages of the peoples of the north are being saved.] Smart news. 30 September 2016.

http://smartnews.ru/regions/yakutsk/11535.html 


\section{Utvrđivanje sintaktičke konvergencije u dvojezičnih govornika ruskoga jezika ijezika sakha}

Članakpokazuje primjenu dvaju osnovnih testova za provjerupromjena uporetku riječiu dvamajezicima u dugogodišnjemu kontaktu: u ruskome jeziku i u jeziku sakha (ili jakutskom). Pretpostavka je da promjene u poretku riječi mogu biti povezane s dubljim strukturnim promjenama i gubitkom jezika. Istraživanja pokazuju da neki govornici prestaju rabiti jezik sakha jer govore ruski: u skupini od 30 govornika četvero ih ne može proizvesti tekst na jeziku sakha, dok je trećina ispitanika proizvela rečenice s pogreškama. Istodobno, u proizvodnji tekstova na ruskome takođerje zabilježen znatan brojpogrešaka koje su odražavale interferencije s drugim jezikom (sakha) ili su posljedica loše usvojenoga jezika. Sociolingvistički je upitnik pokazao visoku razinu podudarnosti između samoprocjene jezične kompetencije govornika u svakome od proučavanih jezika i rezultata naših mjerenja. Štoviše, i vrlo jednostavne provjere kompetencije pokazale su stanovit broj ostalih vrsta pogrešaka te dokazale da su pouzdan pokazatelj sve slabije tečnosti u govoru kao i neupitno početne faze gubitka jezika.

Keywords: contact, word order change, language shift, Sakha, Russian

Ključne riječi: jezični dodiri, promjene u poretku riječi, gubitak jezika, sakha/jakutski, ruski 